\title{
Heavy metals assessment in water, soil, vegetables and their associated health risks via consumption of vegetables, District Kasur, Pakistan
}

\author{
Imtiaz Ashraf ${ }^{1,4} \cdot$ Faizan Ahmad $^{2,4} \cdot$ Atif Sharif $^{3,4} \cdot$ Adnan Raza Altaf $^{1,5} \cdot$ Haipeng Teng ${ }^{1}$
}

Received: 17 November 2020 / Accepted: 31 March 2021 / Published online: 13 April 2021

(c) The Author(s) 2021 OPEN

\begin{abstract}
The consumption of contaminated vegetables has a great impact on human health. Due to this fact, we conduct the study to estimate the heavy metals in groundwater, soil, and vegetables by using the atomic adsorption spectroscopy (AAS) and find out the health risk using THQ and TCR caused by using these vegetables. The mean concentrations of As (0.015$0.40 \mathrm{mg} / \mathrm{L}), \mathrm{Cd}(0.02-0.029 \mathrm{mg} / \mathrm{L}), \mathrm{Co}(0.31-0.38 \mathrm{mg} / \mathrm{L}), \mathrm{Cr}(1.02-1.09 \mathrm{mg} / \mathrm{L}), \mathrm{Cu}(2.14-2.17 \mathrm{mg} / \mathrm{L})$, and Hg (0.01-0.04 mg/L) are high in groundwater from threshold values given by WHO. The mean concentrations of As $(22.17-23.14 \mathrm{mg} / \mathrm{kg}), \mathrm{Cd}$ $(4.21-4.54 \mathrm{mg} / \mathrm{kg}), \mathrm{Cu}(21.24-24.36 \mathrm{mg} / \mathrm{kg})$, and $\mathrm{Pb}(32.12-33.48 \mathrm{mg} / \mathrm{kg})$ are high in soil samples from threshold values given by WHO. The mean concentrations of $\mathrm{As}, \mathrm{Cd}, \mathrm{Pb}, \mathrm{Cr}, \mathrm{Fe}, \mathrm{Hg}$, and $\mathrm{Mn}$ values exceeded the recommended values with concentration ranges: $1.75-4.56,0.41-0.67,2.12-3.12,1.44-4.56,87.12-135.25,2.09-2.64$, and 33.41-129.32 mg/ $\mathrm{Kg}$, respectively. The vegetable sample's average concentration of heavy metals was in decreasing order cabbage ' brinjal ' okra ' tomato. The EDI values for As, Co, and $\mathrm{Hg}$ calculated for both adults and children is high. The target hazard quotients (THQ) for As, $\mathrm{Co}$, and $\mathrm{Hg}$ are greater than the threshold value by consuming vegetables, which indicated the health risk for both adults and children. Similarly, HI due to tomato, cabbage, okra, and brinjal's consumption is ' 1 , with HI values $8.1975,15.3077,8.7312$, and 10.2306 , respectively. This advised the possible health effect in this area by using these vegetables. Target Cancer risk (TCR) exposed the adverse cancer risk persuaded by $\mathrm{As}, \mathrm{Cr}$, and $\mathrm{Hg}$ as their values exceeded the normal range by USEPA by consumption of these vegetables. This study concluded that vegetables imply the total health risk on local people, and regular monitoring of heavy metals is strongly suggested in this region.
\end{abstract}

\section{Article Highlights}

- Heavy metals distribution in this study area is under the impact of urbanization, industrialized and agricultural activities.
- BCF showed the transfer of Fe and $\mathrm{Hg}$ from soil to edible parts of vegetables.

- TCR for $\mathrm{As}, \mathrm{Cd}, \mathrm{Cr}, \mathrm{Ni}$, and $\mathrm{Pb}$ shows the toxicological risk in this region.

Keywords Wastewater irrigation · Groundwater · Target cancer risk · Hazard index · Vegetable $\cdot$ Atomic adsorption spectroscopy

\footnotetext{
$\triangle$ Imtiaz Ashraf, imtiaz907@gmail.com; $\bowtie$ Adnan Raza Altaf, adnan.raza.altaf@gmail.com; Faizan Ahmad, prfaizanahmad@gmail.com; Atif Sharif, atif.sharif@hotmail.com; Haipeng Teng, tenghp@nwu.edu.cn | 1 School of Chemical Engineering, Northwest University, Xi'an, Shaanxi 710069, People's Republic of China. ${ }^{2}$ Frontier Institute of Science and Technology, Xi'an Jiatong University, Xi'an, Shaanxi 710049, People's Republic of China. ${ }^{3}$ College of Chemistry \& Materials Science, Northwest University, Xi'an, Shaanxi 710069, People's Republic of China. ${ }^{4}$ Department of Chemistry, University of Engineering and Technology, Lahore 39161, Punjab, Pakistan. ${ }^{5}$ Institute of Soil \& Environmental Sciences, University of Agriculture, Faisalabad 38040, Pakistan.
} 


\section{Introduction}

Heavy metals influence our environment as they are primary polluting agents in our food source, specifically vegetables [1]. The discharge of industrial waste has the potential of polluting water. This polluted water directly affects soil, agricultural fields, and rivers, which cause to produce multiple sources of pollution [2,3]. Heavy metals flow in soil and water, which is deeply concerned about public health, farming production, and ecological strength [4-7]. Pakistan faces a deficiency of external water resources, so their agricultural activities rely on wastewater usage in city and peri-urban areas [8]. Human activities like industrial waste, transportation, and agriculture emit a large concentration of heavy metal elements on the soil surface and groundwater [9]. Heavy metals such as $\mathrm{Cd}, \mathrm{Ni}$, and $\mathrm{Pb}$ are not required to grow plants. These metals mainly accumulate in plants in hazardous forms, which can cause dangerous diseases in humans and wildlife [10]. These heavy metals are categories as essential and toxic. Fe, $\mathrm{Cu}, \mathrm{Zn}, \mathrm{Co}, \mathrm{Mn}$, Mo are necessary for plant's growth in adequate amount, whereas $\mathrm{Hg}, \mathrm{Cd}, \mathrm{Pb}, \mathrm{Sn}, \mathrm{Cr}$, As are known as toxic metals. Toxic heavy metals also affect plants' growth and cause structural damage and deformation in their physiological and biochemical activities. Heavy metal absorptions in vegetables and nutrition have contrary relationships that influence the various portions of vegetables (protein, fat, and carbohydrate) [11,12]. Many studies have been conducted on heavy metal pollution in developed countries' food chains [13-16].

However, some studies have been conducted in developing regions [17-20]. In Pakistan, published data on heavy metal contamination in the food chain are not substantial, a few reports for references [21-27]. In the farmland in northern Lahore, industrial wastewater and municipal wastewater are usually used to grow vegetables. These vegetables are widely used in urban and rural areas. The purpose of this study was to ensure that the heavy metals added to the effluents seep down to the groundwater and then cause various diseases in human beings living in nearby areas of Kasur, Pakistan. This study comprises of estimating the concentration of selected heavy metals ( $\mathrm{Fe}$, $\mathrm{Hg}, \mathrm{Co}, \mathrm{Mn}, \mathrm{Pb}, \mathrm{Zn}, \mathrm{Cr}, \mathrm{Ni}, \mathrm{Cu}, \mathrm{As}$, and $\mathrm{Cd}$ ) in water, soil, and vegetable's samples near the selected area and finding out the impact of usage of water and vegetables on local people. Some factors such as BCF (bioaccumulation factor), $\mathrm{EDI}$ (estimate daily intake), THQ (target hazard quotient), $\mathrm{HI}$ (health index), and TCR (target cancer risk) (for As, Cd, $\mathrm{Cr}, \mathrm{Ni}$, and $\mathrm{Pb}$ ) were calculated to find out the health risk for human beings living in this area.

\section{Material and methods}

\subsection{The geographical location of the study area}

Kasur (Romanized as Qasūr, meaning palace) has a latitude $31^{\circ} 70 \mathrm{~N}$ and longitude $74^{\circ} 27^{\prime} 0^{\prime \prime} \mathrm{E}$ and is located in the east of Punjab Province, Pakistan-Indian border. The region encompassed by the research area mostly includes small villages and agricultural land irrigated by the river water or groundwater [28]. Significant crops cultivated in this area are sugar cane, maize, wheat, and some vegetables (brinjal, okra, tomatoes, cauliflower, cabbage, and reddish). Kasur city has a traditional industrial setup with many small tannery units existing in the residential areas [28]. Kasur city, rich in the tanning industry, occupies 50\% of Pakistan's entire tanning industry. Out of these existing tanning units, about $90 \%$ of the tanneries have adopted the chrome tanning process [29]. Several possible scattered sources in the tannery area's vicinity may cause subsurface contamination. Therefore, it is impossible to define a single-point source causing this contamination. Drain Rohi is not lined when it comes out of the city. It is also carrying industrial effluent and municipal wastewater, so there is a great possibility of percolating hazardous chemicals into the soil. The above-stated facts mean that the effluent has seeped into the ground. The drains could be line sources of contamination and are causing the area of contamination to expand farther from the tannery area. Due to the relatively high permeability of soil underlying the drain, the groundwater is rapidly contaminated by the hazardous chemicals originating from the tannery effluent [28]. The soils are reddish brown to grayish brown, mostly medium-coarse and medium-textured soils, containing a high percentage of fine to very fine sand and silty clay. The clay part of the soil consists of nonswelling materials, i.e., silty clay loam. The entire area is underlined mostly by sand at various depths, below the soil for the drain [30]. Figure 1 shows the map of study area along with sampling sites.

\subsection{Groundwater, soil, and vegetable sampling}

Forty-eight groundwater samples were collected in triplicate, used for watering the research field, and located near the drainage sites. Forty-eight soil samples from four different areas ( 12 samples from each field) were collected by digging up a monolith $\left(30 \times 30 \times 30 \mathrm{~cm}^{3}\right)$. Two kilograms of soil was collected in triplicate from each field stored in a polyethylene bag and sent to the chemistry laboratory for further analysis. Soil samples were air-dried, crushed, and passed out by a $2 \mathrm{~mm}$ sieve and stored at room temperature. One kilogram of edible parts of each vegetable was 


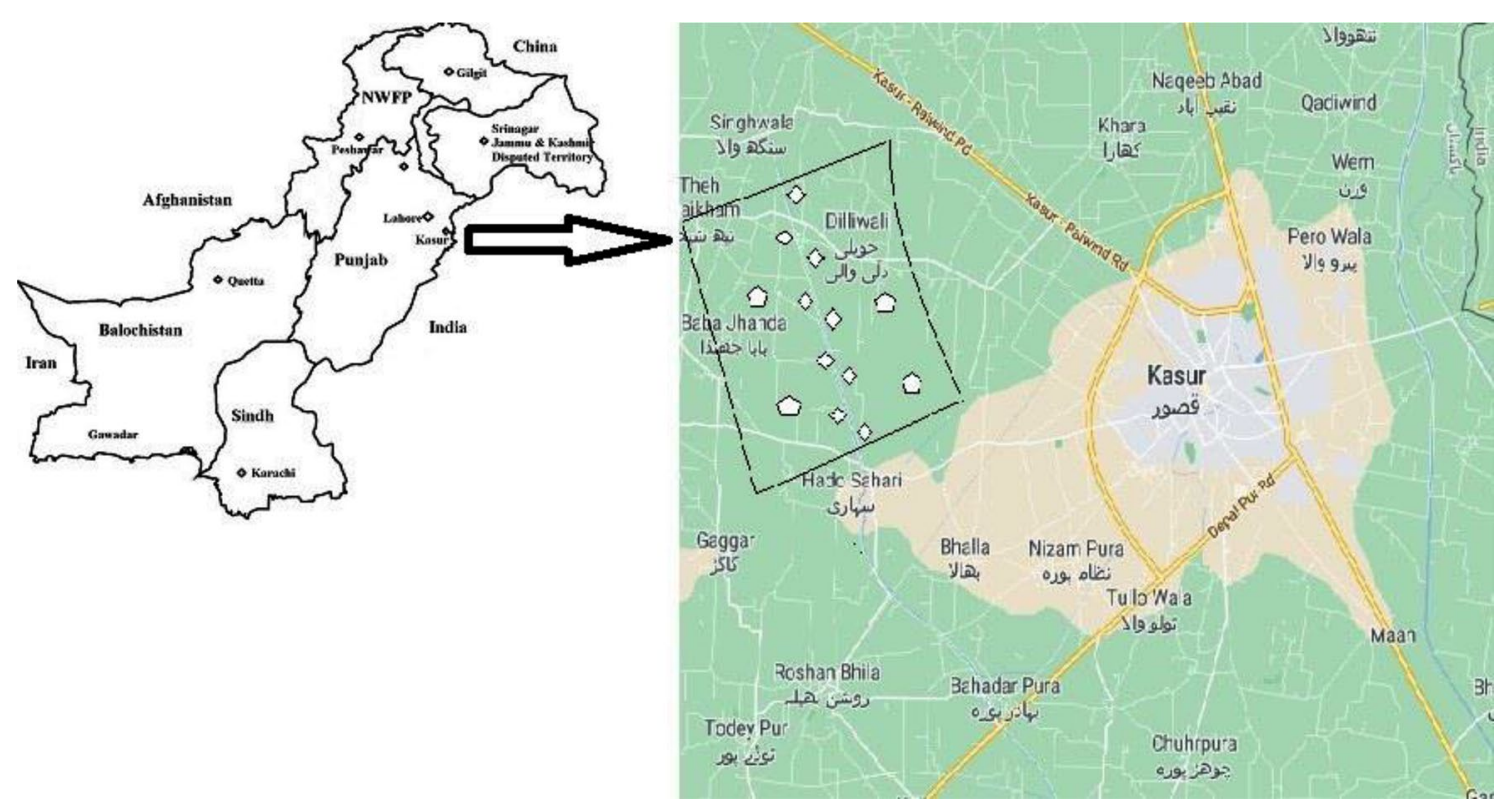

Fig. 1 Map of Pakistan showing the study area and study sites

collected in triplicate from each site and stored in a polyethylene bag. After this, each vegetable is washed out with tap water and then washed three times with deionized water to remove the surface pollutants and other impurities. Then, the vegetables were sliced into small pieces and kept air-dried for two hours. After the air-drying, these samples were poured into a silica plate and kept in an oven at $110^{\circ} \mathrm{C}$ for drying. The dried sample was ground into the mortar until it could pass out from a $2 \mathrm{~mm}$ sieve and then stored in desiccators before putting into a muffle furnace to convert into ash for $12 \mathrm{~h}$ at $500^{\circ} \mathrm{C}$ [31].

\subsection{Physiochemical properties of samples}

Groundwater and soil pH were calculated by $\mathrm{pH}$ meter by Maclean [32]. The sample's conductivity was calculated by an electrical conductivity meter Cyberscan Pc 510 (Eutech instrument). For BOD Jenway 970 (Cole-Parmer Instrument), HACH methods are used (8043). For COD (Lovibond RD $125 \mathrm{~m}$ ), HACH method was used (8000). Total nitrogen and total phosphate of soil were determined by Bremner and Mulvaney [33].

\subsection{Samples digestion for determination of heavy metals}

Large particles and wreckages from the soil sample were removed and dried at $110^{\circ} \mathrm{C}$ in the oven. One gram of each sample was placed in a flask, and $15 \mathrm{~mL}$ acid mixture of 5:1:1 $\left(70 \% \mathrm{HNO}_{3}, 70 \% \mathrm{H}_{2} \mathrm{SO}_{4}\right.$ and $\left.65 \% \mathrm{HCLO}_{4}\right)$ was added and kept in the mechanical shaker at $80^{\circ} \mathrm{C}$ until clear solution obtained. After cooling, the solution was filtered with Whatman no 42 filter paper, then poured into a 50-ml volumetric flask, and diluted until the mark for further analysis. Samples were analyzed for different heavy metals such as $\mathrm{Cd}, \mathrm{Ni}, \mathrm{Cu}, \mathrm{Zn}, \mathrm{Fe}, \mathrm{Pb}$, and $\mathrm{Cr}$ with the atomic absorption spectrometer's help (Model GBC-932 plus U.K). Analysis using AAS was carried out at the most analytical spectral lines of the metals $(\mathrm{Zn} 228.8 \mathrm{~nm}, \mathrm{~Pb} 217 \mathrm{~nm}, \mathrm{Ni} 232 \mathrm{~nm}$, Cu 324.8 nm, Cr 357.9 nm, Fe 309 nm, Cd 248.3 nm, and As $193.7 \mathrm{~nm}$ ) [34-36]. For As determination, the slotted tube atom trap with an inert gas/hydrogen was held in the flame by a simple holder. The burner clips were used to enhance the flame sensitivity and improve the detection limit for As. Ten milliliters of water sample was digested with $2 \mathrm{ml} \mathrm{HNO}_{3}$ and $5 \mathrm{ml} \mathrm{HCl}$ and heated at $95{ }^{\circ} \mathrm{C}$ until the transparent solution was obtained, and then the solution was filtered and cooled. Total volume was adjusted at $50 \mathrm{ml}$, and the heavy metals were estimated by AAS [34]. 


\subsection{Bioconcentration factor}

The bioconcentration factor was calculated as given in Eq. (1):

$\mathrm{BCF}=\frac{C_{\text {plant }}}{C_{\text {soil }}}$

$C_{\text {plant }}$ shows the metal concentration in edible parts of vegetables, and $C_{\text {soil }}$ shows the metal concentration in soil. If $B C F$ is greater than one, then the plant is a potential accumulator of heavy metal and should be analyzed.

\subsection{Health hazard factors}

\subsubsection{Estimated daily intake (EDI)}

The daily intake of vegetables is calculated from Eq. (2):

$\mathrm{EDI}_{\mathrm{veg}}=\frac{C_{\mathrm{m}} \times C_{\mathrm{f}} \times F_{\mathrm{IR}} \times E_{\mathrm{f}} \times D_{e}}{W_{\mathrm{b}} \times T_{\mathrm{av}}} \times 10^{-3}$

where $C_{\mathrm{m}}$ represents the metal concentration $(\mathrm{mg} / \mathrm{kg}$ of dry weight), $E_{f}$ represents the exposure frequency $(365 \mathrm{~d} / \mathrm{a}), D_{\mathrm{e}}$ represents the exposure duration (70), $T_{\mathrm{av}}$ represents the average time of exposure ( 365 days $\times 70$ ). $F_{\mathrm{IR}}$ represents the average food consumption (300-350 g/ person/day) given by WHO [37]. In this study, we used mean of this consumption 325/115 g/person/day, $C_{f}$ represents the conversion factor of vegetable into dry weight (0.085) [38] and $W_{\mathrm{b}}$ represents the average body weight of consumer (70/15 kg) (FAO/WHO) [39].

\subsubsection{Target hazard quotient (THQ)}

The target hazard quotient is calculated using Eq. (3) [33]:

$\mathrm{THQ}=\frac{E D I}{D_{\mathrm{f}}}$

$E D I$ is estimated daily intake and Df represents the reference dose. If the THQ value is greater than one, then there is a chance for a noncarcinogenic effect related to values. If THQ is less than one, it will be assumed to be safe for noncarcinogenic effects [40]. Overall data for find out the THQ are compiled in Table 1.

\subsubsection{Hazard index (HI)}

It is calculated by the given formula in Eq. (4) [41, 42]:
$\mathrm{THQ}_{\mathrm{Mn}}=\frac{\mathrm{EDI} \times C_{\mathrm{Mn}}}{D_{\mathrm{fMn}}}$

where $C_{\mathrm{Mn}}$ represents the concentration of manganese and $D_{\mathrm{fMn}}$ represents the oral reference dose of manganese. If $\mathrm{HI}$ is greater than one, then there is a health significance resulting from exposure to a particular element. This $\mathrm{HI}$ value greater than one is not acceptable. $\mathrm{HI}$ values are classified into negligible, low risk, medium risk, and high risk [43].

\subsubsection{Cancer risk}

It can be calculated by using Eq. (6)

$\mathrm{CR}_{\text {veg }}=\mathrm{EDI} \times \mathrm{CPS}_{\mathrm{o}}$

$\mathrm{TCR}=\sum \mathrm{CR}$

where EDI represents the estimated daily intake and CPSo represents the oral cancer slope factor. Some CPS values for $\mathrm{As}, \mathrm{Pb}, \mathrm{Ni}, \mathrm{Cr}$, and $\mathrm{Cd}$ are given in Table 1 .

\subsection{Statistical analysis of heavy metals}

Statistical analysis was done using Origin 2018 to evaluate the significant differences between heavy metals concentration in the vegetables, soil, and water samples. Principle component analysis ( $\mathrm{PCA}$ ) was used to determine the potential heavy metal source in water, soil, and vegetable samples.

\section{Results and discussion}

\subsection{Physiochemical properties and heavy metals in groundwater}

Heavy metals contaminate groundwater used for drinking purposes and cultivation process through chemical use for agricultural, municipal waste, and industrial effluents. The physiochemical parameter of groundwater is summarized in Table 2, which shows that $\mathrm{pH}, \mathrm{ECs}$, BOD, COD, and TDS of groundwater are in a permissible range given by the $\mathrm{WHO}$ [37]. This region's mean $\mathrm{pH}$ values range from 7.93 to 8.17 , which lie within the productive water range of 6-9 [44]. Some of these heavy metals in groundwater are good for human health in trace amounts, but they produce water pollution and become

$\mathrm{HI}=\sum \mathrm{THQ}=\mathrm{THQ}_{\mathrm{Mn}}+\mathrm{THQ}_{\mathrm{Pb}}+\mathrm{THQ}_{\mathrm{Co}}+\mathrm{THQ}_{\mathrm{Cd}}+\mathrm{THQ}_{\mathrm{Fe}}+\mathrm{THQ}_{\mathrm{Ni}}+\mathrm{THQ}_{\mathrm{Zn}}+\mathrm{THQ}_{\mathrm{Cr}}$ 
Table 1 Parameters used in EDI, THQ, and TCR

\begin{tabular}{|c|c|c|c|}
\hline Parameters (units) & Vegetable & & References \\
\hline$C_{f}$ & & 0.085 & [63] \\
\hline$C_{\mathrm{m}}$ (mg/kg dry weight) & & Table 5 & This study \\
\hline$D_{\mathrm{e}}$ (years) & & 70 & {$[62]$} \\
\hline$E_{\mathrm{f}}$ (days) & & 365 & {$[62]$} \\
\hline$F_{\mathrm{IR}}$ (g/day) & & $325 / 115$ & {$[37]$} \\
\hline$T_{\mathrm{av}}$ (days) & & 25550 & - \\
\hline$W_{\mathrm{b}}(\mathrm{kg})$ & & $70 / 15$ & [39] \\
\hline \multirow[t]{11}{*}{ Oral reference dose $\left(D_{f}\right)(\mathrm{mg} / \mathrm{kg} /$ day $)$} & As & 0.0003 & {$[63]$} \\
\hline & $\mathrm{Cd}$ & 0.001 & \\
\hline & Co & 0.0003 & \\
\hline & $\mathrm{Cr}$ & 0.003 & \\
\hline & $\mathrm{Cu}$ & 0.04 & \\
\hline & $\mathrm{Fe}$ & 0.7 & \\
\hline & $\mathrm{Hg}$ & 0.0003 & \\
\hline & $\mathrm{Mn}$ & 0.14 & \\
\hline & $\mathrm{Ni}$ & 0.02 & \\
\hline & $\mathrm{Pb}$ & 0.0035 & \\
\hline & $\mathrm{Zn}$ & 0.3 & \\
\hline \multirow[t]{5}{*}{ Oral cancer slope factor $\left(\mathrm{CPS}_{\mathrm{o}}\right)(\mathrm{mg} / \mathrm{kg} / \text { day })^{-1}$} & As & 1.5 & [63] \\
\hline & $\mathrm{Cd}$ & 0.38 & \\
\hline & $\mathrm{Cr}$ & 0.5 & \\
\hline & $\mathrm{Pb}$ & 0.0085 & \\
\hline & $\mathrm{Ni}$ & 1.7 & \\
\hline
\end{tabular}

Table 2 Physio-chemical parameter and heavy metals in groundwater

\begin{tabular}{|c|c|c|c|c|c|}
\hline \multirow[t]{2}{*}{ Parameters } & \multicolumn{4}{|l|}{ Location } & \multirow[t]{2}{*}{ Reference values } \\
\hline & $\begin{array}{l}\text { Near tomato } \\
\text { cultivation }\end{array}$ & Near brinjal cultivation & $\begin{array}{l}\text { Near cabbage } \\
\text { cultivation }\end{array}$ & Near okra cultivation & \\
\hline $\mathrm{pH}$ & $8.03(0.44)$ & $8.12(1.4)$ & $8.17(2.4)$ & $7.89(1.9)$ & $6.5-8.5$ \\
\hline $\mathrm{ECs}(\mu \mathrm{S} / \mathrm{cm})$ & $1048(2.6)$ & $1224(5.78)$ & 1047(3.85) & 1089(3.9) & 3000 \\
\hline $\mathrm{BOD}\left(\mathrm{mgL}^{-1}\right)$ & $15(1.4)$ & $24(3.8)$ & $21(2.1)$ & $31(4.6)$ & 150 \\
\hline $\operatorname{COD}\left(\mathrm{mgL}^{-1}\right)$ & $31(1.1)$ & $29(1.5)$ & $34(1.9)$ & $41(2.7)$ & 80 \\
\hline $\operatorname{TDS}\left(\mathrm{gL}^{-1}\right)$ & $0.52(0.20)$ & $0.58(0.26)$ & $0.65(0.31)$ & $0.47(0.24)$ & $1.0-3.50$ \\
\hline Metals & \multicolumn{4}{|c|}{ Levels of heavy metals (mg/L) } & \\
\hline As & $0.02(0.1)$ & $0.03(0.2)$ & $0.04(0.4)$ & $0.02(0.3)$ & 0.01 \\
\hline $\mathrm{Cd}$ & $0.02(0.6)$ & $0.03(0.3)$ & $0.03(0.4)$ & $0.02(0.1)$ & 0.01 \\
\hline Co & $0.32(0.4)$ & $0.38(0.8)$ & $0.37(0.9)$ & $0.31(0.7)$ & 0.05 \\
\hline $\mathrm{Cr}$ & $1.02(0.1)$ & $1.05(0.6)$ & $1.07(0.7)$ & $1.09(0.2)$ & 0.05 \\
\hline $\mathrm{Cu}$ & $2.14(1.4)$ & $2.17(1.7)$ & $2.16(1.9)$ & $2.14(1.5)$ & 0.005 \\
\hline $\mathrm{Fe}$ & $0.44(0.3)$ & $0.41(0.2)$ & $0.49(0.4)$ & $0.54(0.1)$ & 2.0 \\
\hline $\mathrm{Hg}$ & $0.04(0.001)$ & $0.02(0.4)$ & $0.01(0.6)$ & $0.03(0.5)$ & 0.005 \\
\hline $\mathrm{Mn}$ & $0.25(0.5)$ & $0.28(0.3)$ & $0.31(0.4)$ & $0.29(0.7)$ & 0.5 \\
\hline $\mathrm{Ni}$ & $0.02(0.002)$ & $0.02(0.01)$ & $0.23(0.04)$ & $0.21(0.02)$ & 0.02 \\
\hline $\mathrm{Pb}$ & $0.01(0.1)$ & $0.02(0.01)$ & $0.01(0.001)$ & $0.01(0.1)$ & 0.05 \\
\hline $\mathrm{Zn}$ & $2.8(1.30)$ & $2.4(1.1)$ & $3.4(1.4)$ & $2.9(1.4)$ & 5.0 \\
\hline
\end{tabular}

Each value is the mean of 12 samples; values in square brackets show the standard deviation 
threat for human health when their amount exceeded. The heavy metals in groundwater exceeded the permissible limit set by WHO [37]. The heavy metal concentration in groundwater is shown in Table 2, and the highest concentration calculated for As $(0.04 \pm 0.4 \mathrm{mg} / \mathrm{L}), \mathrm{Cd}$ (0.03 $\pm 0.4 \mathrm{mg} / \mathrm{L}), \mathrm{Co}(0.38 \pm 0.8 \mathrm{mg} / \mathrm{L}), \mathrm{Cr}(1.09 \pm 0.2 \mathrm{mg} / \mathrm{L})$, $\mathrm{Cu}(2.17 \pm 1.7 \mathrm{mg} / \mathrm{L})$, and $\mathrm{Hg}(0.04 \pm 0.001 \mathrm{mg} / \mathrm{L})$ exceeded the permissible limit set by WHO [37]. While the highest concentration for $\mathrm{Fe}(0.54 \pm 0.1 \mathrm{mg} / \mathrm{L}), \mathrm{Mn}(0.31 \pm 0.4 \mathrm{mg} / \mathrm{L})$, $\mathrm{Ni}(0.02 \pm 0.01 \mathrm{mg} / \mathrm{L}), \mathrm{Pb}(0.02 \pm 0.01 \mathrm{mg} / \mathrm{L})$, and $\mathrm{Zn}$ $(3.4 \pm 1.4 \mathrm{mg} / \mathrm{L})$ was found in the permissible range. In recent studies, the allowable amount of groundwater in various Pakistan regions has far exceeded the limit. The previous study found that the amount of metals $\mathrm{Cd}(0.04)$, $\mathrm{Co}$ (0.15), $\mathrm{Cr}$ (1.32), $\mathrm{Fe}(0.56), \mathrm{Mn}(0.07), \mathrm{Ni}(0.11), \mathrm{Pb}(0.14)$, and $\mathrm{Zn}(0.14)(\mathrm{mg} / \mathrm{L})$ is mainly used for groundwater near the Kasur Industrial Zone in Pakistan, which is many times higher than the WHO standard [30]. ULLAH [45] found the high values of $\mathrm{Mn}(0.03), \mathrm{Zn}(0.16), \mathrm{Pb}(0.49), \mathrm{Fe}(0.30), \mathrm{Cu}$ (0.06), Ni (0.10) and $\mathrm{Cr}(0.03)$ in groundwater of Sialkot, Pakistan. Besides, Haq [46] also reported the Pb concentration $(0.146 \mathrm{mg} / \mathrm{L})$ in groundwater in 18 areas of Karachi, which exceeded the allowable limit $(0.05 \mathrm{mg} / \mathrm{L})$ set by the WHO.

\subsection{Physiochemical properties of soil}

Physiochemical properties analyzed for the soil under the different vegetables used in this study are given in Table 3. The analyzed soil pH varies from 8.09 to 8.34 , which revealed that the study area is slightly alkaline [16]. The electrical conductivity (ECs) values vary from 148 to $169 \mu \mathrm{S} / \mathrm{cm}$, which means that soil has a balanced nutrient amount for plant growth [16]. The soil's total nitrogen content ranges from 0.048 to 0.057 , which reveals that groundwater has less nitrogen content. Total phosphate values in the analyzed soil vary from 0.058 to 0.071 . Lower phosphate values in this soil showed that soil's $\mathrm{pH}$ plays a vital role in the bioavailability of phosphorous plants [47]. The moisture content of the soil samples analyzed under this study varies from 24.8 to $27.4 \%$.

\subsection{Level of heavy metals in soil and vegetables}

\subsubsection{Heavy metals in soil samples}

The heavy metal concentration in soil from the study area has been assessed. The obtained data are presented in Table 4, which demonstrates that all soil samples are positive for heavy metals. The result revealed that As concentration ranged from 22.39 to $23.14 \mathrm{mg} / \mathrm{kg}$, which was higher than the permissible range given by US-EPA $(14 \mathrm{mg} / \mathrm{kg}$ ) for agricultural soil. The high concentration of As indicated that metal and its compound are released from industries situated near this area [48]. Cd concentrations ranging from 4.21 to $4.54 \mathrm{mg} / \mathrm{kg}$ have been found higher than US-EPA's normal values $(0.3 \mathrm{mg} / \mathrm{kg})$. The Co $(7.31-7.56 \mathrm{mg} / \mathrm{kg})$ and $\mathrm{Cr}(23.25-25.64 \mathrm{mg} / \mathrm{kg})$ concentration ranges in this study have been found in the permissible range. The concentration range of $\mathrm{Cu}(21.32-24.36 \mathrm{mg} /$ $\mathrm{kg}$ ) is slightly high in all soil samples from their permissible range. Previous study values of $\mathrm{Cd}(2-3.4 \mathrm{mg} / \mathrm{kg}), \mathrm{Cr}$ $(54.1-210.2 \mathrm{mg} / \mathrm{kg})$, and $\mathrm{Cu}(31.2-60.8 \mathrm{mg} / \mathrm{kg})$ reported in this Kasur area resemble those of the current study [49]. The mean concentration of Fe (51.32-56.28 mg/ $\mathrm{kg}$ ) in cultivation soil was found low for elevated iron as described by a previous study [50] but somehow related to the study done by Rattan [51]. The concentration ranges of $\mathrm{Hg}(0.21-0.27 \mathrm{mg} / \mathrm{kg}), \mathrm{Mn}(1248-1341 \mathrm{mg} / \mathrm{kg})$, and $\mathrm{Ni}$ $(21.36-21.94 \mathrm{mg} / \mathrm{kg})$ in this cultivation soil were found within the permissible range. The concentration ranges of $\mathrm{Pb}(32.12-33.48 \mathrm{mg} / \mathrm{kg})$ and $\mathrm{Zn}(91.36-94.56 \mathrm{mg} / \mathrm{kg})$ were found higher than the permissible range of all soil samples. The $\mathrm{Pb}$ and $\mathrm{Zn}$ concentration corresponds with the previous study values $(23-35 \mathrm{mg} / \mathrm{kg}$ and $55.13-95.23 \mathrm{mg} /$ $\mathrm{kg}$ ) conducted in this area [8]. In general, this study's data revealed that the cultivation soil under all vegetables is contaminated with a high concentration of $\mathrm{As}, \mathrm{Cd}, \mathrm{Cu}, \mathrm{Pb}$, and $\mathrm{Zn}$. Their limits have exceeded their normal range given by the WHO [37].
Table 3 Physiochemical parameters of the soil of the study area

\begin{tabular}{lllll}
\hline Parameters (units) & $\begin{array}{l}\text { Under } \\
\text { tomato culti- } \\
\text { vation }\end{array}$ & Under brinjal cultivation & $\begin{array}{l}\text { Under cab- } \\
\text { bage cultiva- } \\
\text { tion }\end{array}$ & Under okra cultivation \\
\hline $\mathrm{pH}$ & $8.28(0.17)$ & $8.21(0.14)$ & $8.34(0.13)$ & $8.09(0.15)$ \\
$\mathrm{ECs}(\mu \mathrm{S} / \mathrm{cm})$ & $169(4.5)$ & $161(4.2)$ & $154(2.3)$ & $148(1.7)$ \\
Total nitrogen (\%) & $0.054(0.002)$ & $0.048(0.007)$ & $0.057(0.001)$ & $0.052(0.004)$ \\
Total phosphate (\%) & $0.063(0.002)$ & $0.067(0.005)$ & $0.058(0.006)$ & $0.071(0.011)$ \\
Moisture content (\%) & $27.18(0.46)$ & $24.8(0.41)$ & $26.1(0.37)$ & $27.4(0.33)$ \\
\hline
\end{tabular}

Each value is the mean of 12 soil sample, and values in square brackets show the standard deviation 
Table 4 Heavy metals concentration in soil samples

\begin{tabular}{|c|c|c|c|c|c|}
\hline \multirow[t]{2}{*}{ Metals } & \multicolumn{4}{|c|}{ Levels of heavy metals $(\mathrm{mg} / \mathrm{kg})$} & \multirow{2}{*}{$\begin{array}{l}\text { References concen- } \\
\text { tration in soil (mg/ } \\
\mathrm{kg} \text { ) }\end{array}$} \\
\hline & Under tomato cultivation & Under brinjal cultivation & Under cabbage cultivation & Under okra cultivation & \\
\hline As & $22.39(0.073)$ & $22.89(0.061)$ & $23.14(0.052)$ & $22.73(0.047)$ & $14^{\mathrm{a}, \mathrm{b}}$ \\
\hline $\mathrm{Cd}$ & $4.32(0.173)$ & $4.54(0.145)$ & $4.21(0.164)$ & $4.36(0.124)$ & $\leq 0.3^{\mathrm{a}, \mathrm{b}}$ \\
\hline Co & $7.31(0.063)$ & $7.51(0.054)$ & $7.39(0.049)$ & $7.56(0.039)$ & $8^{\mathrm{a}, \mathrm{b}}$ \\
\hline $\mathrm{Cr}$ & $24.95(0.73)$ & $23.25(0.69)$ & $25.64(0.57)$ & $24.31(0.65)$ & $100^{\mathrm{a}, \mathrm{b}}$ \\
\hline $\mathrm{Cu}$ & $23.34(0.17)$ & $21.32(0.19)$ & $24.36(0.21)$ & $22.36(0.14)$ & $20^{a, b}$ \\
\hline $\mathrm{Fe}$ & $56.28(0.12)$ & $52.31(0.16)$ & $54.36(0.19)$ & $51.32(0.14)$ & \\
\hline $\mathrm{Hg}$ & $0.23(0.021)$ & $0.21(0.019)$ & $0.27(0.023)$ & $0.24(0.022)$ & $\leq 0.3^{\mathrm{a}, \mathrm{b}}$ \\
\hline $\mathrm{Mn}$ & $1248.69(34.51)$ & $1324.74(35.12)$ & $1298.25(34.12)$ & $1341.14(33.98)$ & $2000^{a, b}$ \\
\hline $\mathrm{Ni}$ & $21.45(0.29)$ & $21.36(0.27)$ & $21.94(0.21)$ & $21.51(0.25)$ & $50^{a, b}$ \\
\hline $\mathrm{Pb}$ & $33.48(0.18)$ & $32.12(0.19)$ & $33.24(0.17)$ & $33.12(0.16)$ & $10^{a, b}$ \\
\hline $\mathrm{Zn}$ & $92.37(0.17)$ & $94.56(0.21)$ & $92.45(0.19)$ & $91.36(0.22)$ & $50^{a, b}$ \\
\hline
\end{tabular}

Each value is the mean of 12 soil sample; values in square brackets show the standard deviation

a [37]

$\mathrm{b}[39]$

\subsubsection{Heavy metals in vegetables}

In current ages, food hygiene and safety have become an important challenge in emerging countries due to improper management of wastage released from industries. Thus, the heavy metal concentration in commonly consumed vegetables was analyzed to ensure food safety and quality in this study.

The data of heavy metal concentration for all cultivated vegetables in this study are shown in Table 5 . The mean concentration of As $(1.75-4.46 \mathrm{mg} / \mathrm{kg})$ is higher than the normal values given by FAO/WHO [39]. The previous study conducted in Bangladesh shows the mean concentration of As in leafy and fruity vegetables is $0.28 \mathrm{mg} /$ $\mathrm{kg}(0.09-0.43 \mathrm{mg} / \mathrm{kg})$ and $2.24 \mathrm{mg} / \mathrm{kg}(0.009-7.9 \mathrm{mg} /$ $\mathrm{kg})$, respectively $[52,53]$. These result revealed that As concentration is high than the previous study conduct in this region, which is due to the usage of As-enriched fertilizer to cultivate vegetables [54]. Cd's mean concentration ranged $0.41-0.67 \mathrm{mg} / \mathrm{kg}$ in all vegetables collected from the study area. While $\mathrm{Cd}$ concentration values in previous study conduct in Pakistan are $(0.02-0.08 \mathrm{mg} / \mathrm{kg})$, $(0.01-0.69 \mathrm{mg} / \mathrm{kg}),(0.093-4.09 \mathrm{mg} / \mathrm{kg})[55-57]$, and study conduct in Bangladesh is $(0.001-2.2 \mathrm{mg} / \mathrm{kg})$ [58], respectively. The $\mathrm{Cd}$ level in all vegetables used in this study is higher than the normal values given by FAO [39]. This is due to the extreme usage of inorganic fertilizer, wastewater irrigation, and metal emission from industries.

Co's mean concentration varied from 0.57 to $1.36 \mathrm{mg} /$ $\mathrm{kg}$ in all vegetable samples collected from the study area. Compared with previous studies conducted in Pakistan, the current study result varied from 1.08 to $13.6 \mathrm{mg} / \mathrm{kg}$ in different vegetables that fall within the permissible range [27]. The mean concentration of $\mathrm{Cr}$ ranged from 1.44 to $4.56 \mathrm{mg} / \mathrm{kg}$ in vegetable samples. The $\mathrm{Cr}$ concentration in a previous study $(0.2-3.98 \mathrm{mg} / \mathrm{kg})$ done in Pakistan [27] resembles this study, but $\mathrm{Cr}$ concentration is lower than the previous study done in Bangladesh $(2.1-33.16 \mathrm{mg} / \mathrm{kg}$ ) [19]. The mean concentration of Fe (87.12-135.25 mg/kg), $\mathrm{Hg}(2.09-2.65 \mathrm{mg} / \mathrm{kg}), \mathrm{Mn}(33.41-129.32 \mathrm{mg} / \mathrm{kg})$ is found high in all vegetables also from the previous study conducted in Pakistan [59] and Bangladesh [57]. Fe metal is used in photosynthesis and chlorophyll synthesis. That is why all vegetables contain more amount of iron. Ni's mean concentration ranged from 1.36 to $3.12 \mathrm{mg} / \mathrm{kg}$, which resembled the values obtained with the previous study, whose mean concentration varied from 1.41 to $37.52 \mathrm{mg} /$ $\mathrm{kg}$ [19]. The mean concentration of $\mathrm{Pb}$ in all vegetable samples varied from 2.12 to $3.21 \mathrm{mg} / \mathrm{kg}$, which is much higher than the previous study done in this region [27, 59]. The $\mathrm{Pb}$ concentration resembled the values obtained from the study conducted in India and Bangladesh [19, $57,58]$. Pb's high value in all vegetable samples indicated that these fields were irrigated with the untreated wastewater discharge from paint and $\mathrm{Pb}$ smelting industries in this region [19]. The mean concentration of $Z n$ varies from 20.36 to $22.67 \mathrm{mg} / \mathrm{kg}$. Zn's value in all vegetable samples is higher than the previous study conducted in Pakistan [55]. In contrast, the $Z n$ concentration coincides with the study conduct in Bangladesh [57].

It is observed from Table 5 that the heavy metals accumulation in the leafy vegetable is higher than the fruity vegetables because leafy vegetables have a high transpiration rate to sustain the plant growth and moisture content 
in vegetables $[19,27]$. Also, heavy metal concentration in vegetables highly depends on environmental and geological location. The current study results were compared with previous studies, and the data are given in Table 6.

\subsection{Source analysis of heavy metals in vegetables}

Pearson's correlation coefficient matrix method was used to determine the interrelationship between the vegetable sample's heavy metals, as shown in Table 7. The intermetal interface shows the causes and pathways of heavy metals in vegetable samples. As shows the strong positive relationship with the $\mathrm{Cd}$ (0.939), Co (0.956), $\mathrm{Cr}(0.987), \mathrm{Fe}$ (0.996), $\mathrm{Hg}(0.951)$, and $\mathrm{Mn}(0.977)$, while a moderately strong relationship with $\mathrm{Ni}(0.646)$ and $\mathrm{Pb}(0.628)$ and strong negative relationship with $\mathrm{Cu}(-0.790)$ and $\mathrm{Zn}$ $(-0.916)$. Cd, Co, Cr, Cu Fe, Hg, and $\mathrm{Ni}$ show a strong correlation. In contrast, $\mathrm{Pb}$ and $\mathrm{Zn}$ do not offer any significant strong and negative correlation with other metals. The high correlation coefficient between metals shows the common source, interdependence, nearly or similar metal accumulation in vegetable samples [17].

To determine the hypothetical source of heavy metals (natural or human) in vegetable samples, principal component analysis (PC) was performed according to the standard procedure described in the literature $[60,61]$. The PCA was completed in a tabular and dimensionless standardized form of the dataset and is presented in Table 8 and Fig. 2. Two principal components (PC) were obtained, and their variances were explained by $84.996 \%$ and $9.129 \%$ for this study. Overall, PCA reveals two significant categories of 11 heavy metals studied in vegetables. PC1 is highly synchronized with $\mathrm{As}, \mathrm{Cd}, \mathrm{Co}, \mathrm{Cr}, \mathrm{Fe}, \mathrm{Hg}, \mathrm{Ni}, \mathrm{Mn}$, and $\mathrm{Pb}$, while $\mathrm{PC2}$ is highly synchronized with $\mathrm{Cu}$ and $\mathrm{Zn}$. The sources of PC1 and PC2 can be considered as mixed sources of human input, especially industrial pollution and agricultural activities in the study area. Vehicle emissions and environmental reserves were released by burning coal and fuel, and it is believed that vegetable samples have been collected in these metals in urban areas. Because heavy metals are released into the atmosphere and accumulated by plants, PCA analysis shows that the intensity of similar heavy metals in vegetables is not the same.

\subsection{Bioconcentration factor (BCF)}

The deposition and transfer route of heavy metals from soil to the edible part of vegetables is the main entry of heavy metals in food [58]. We have calculated heavy metal transferability of soil to plant for vegetables used in this study which is shown in Table 9. BCF factor for heavy metals $\mathrm{As}, \mathrm{Co}, \mathrm{Cd}, \mathrm{Cr}, \mathrm{Cu}, \mathrm{Mn}, \mathrm{Ni}, \mathrm{Pb}$, and $\mathrm{Zn}$ is less than one, which indicates that these metals are not accumulating in the plant through soil. While the BCF for Fe accumulating in tomato is (1.55), Brinjal (1.88), cabbage (2.49), and okra (1.84) and BCF for $\mathrm{Hg}$ accumulating in tomato (9.35), Brinjal (11.00), cabbage (9.78), and okra (8.71). BCF for each vegetable was subjected to a statistical test (oneway ANOVA test) to estimate the existence or absence of numerical difference between these vegetables and result revealed that the $95 \%$ significantly different expect $\mathrm{Cd}, \mathrm{Zn}$, and $\mathrm{Pb}$ [42].
Table 5 Heavy metals in vegetable samples

\begin{tabular}{|c|c|c|c|c|c|}
\hline \multirow[t]{2}{*}{ Metals } & \multicolumn{4}{|c|}{ Levels of heavy metals in vegetables (mg/kg dry weight) } & \multirow{2}{*}{$\begin{array}{l}\text { Allowable } \\
\text { concentration } \\
(\mathrm{mg} / \mathrm{kg})\end{array}$} \\
\hline & Tomato & Brinjal & Cabbage & Okra & \\
\hline As & $1.75(0.026)$ & $2.65(0.021)$ & $4.56(0.029)$ & $2.31(0.019)$ & $0.1^{\mathrm{a}, \mathrm{b}}$ \\
\hline $\mathrm{Cd}$ & $0.44(0.028)$ & $0.53(0.017)$ & $0.67(0.024)$ & $0.41(0.025)$ & $0.05^{a, b}$ \\
\hline Co & $0.66(0.032)$ & $0.84(0.021)$ & $1.36(0.036)$ & $0.57(0.019)$ & $10^{a, b}$ \\
\hline $\mathrm{Cr}$ & $1.44(0.027)$ & $2.36(0.031)$ & $4.56(0.021)$ & $1.56(0.029)$ & $2.3^{\mathrm{a}, \mathrm{b}}$ \\
\hline $\mathrm{Cu}$ & $12.45(0.107)$ & $10.23(0.136)$ & $9.24(0.121)$ & $13.65(0.211)$ & $40^{\mathrm{a}, \mathrm{b}}$ \\
\hline $\mathrm{Fe}$ & $87.12(0.845)$ & $98.32(0.412)$ & $135.25(1.12)$ & $94.31(0.213)$ & $42.5^{a, b}$ \\
\hline $\mathrm{Hg}$ & $2.15(0.025)$ & $2.31(0.021)$ & $2.64(0.029)$ & $2.09(0.013)$ & $0.01-0.3^{a, b}$ \\
\hline $\mathrm{Mn}$ & $33.41(0.485)$ & $45.36(0.512)$ & $129.32(2.136)$ & $36.12(0.243)$ & $10^{a}$ \\
\hline $\mathrm{Ni}$ & $2.35(0.037)$ & $1.36(0.023)$ & $3.12(0.031)$ & $1.75(0.029)$ & $10^{a}$ \\
\hline $\mathrm{Pb}$ & $2.84(0.072)$ & $2.56(0.042)$ & $3.21(0.031)$ & $2.12(0.054)$ & $0.1-0.3^{a, b}$ \\
\hline $\mathrm{Zn}$ & $22.67(0.878)$ & $21.56(0.756)$ & $20.36(0.659)$ & $21.36(0.423)$ & $2.3-50^{a, b}$ \\
\hline
\end{tabular}

Each value is the mean of 12 soil samples; values in square brackets show the standard deviation a[37]

${ }^{b}[39]$ 


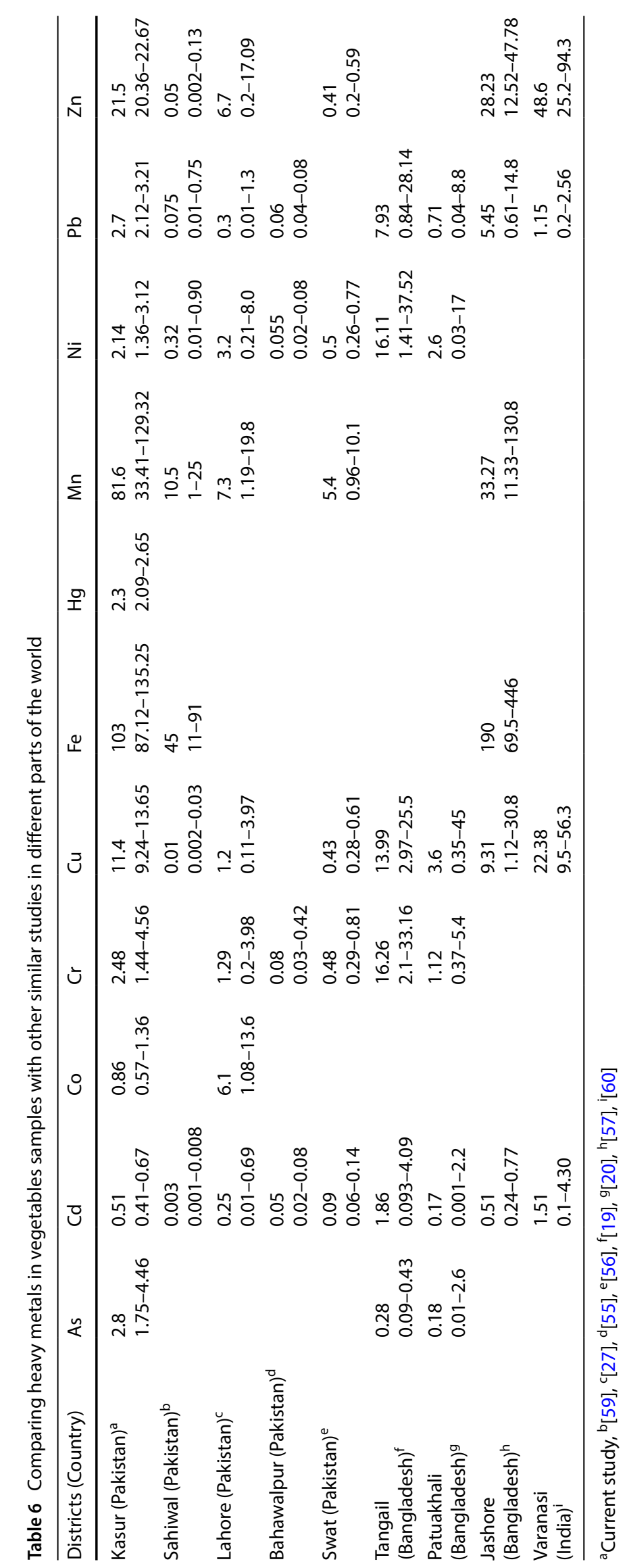


Table 7 Correlation coefficient matrix of heavy metals in the vegetable sample

\begin{tabular}{llllllllllll}
\hline Metals & $\mathrm{As}$ & $\mathrm{Cd}$ & $\mathrm{Co}$ & $\mathrm{Cr}$ & $\mathrm{Cu}$ & $\mathrm{Fe}$ & $\mathrm{Hg}$ & $\mathrm{Mn}$ & $\mathrm{Ni}$ & $\mathrm{Pb}$ & $\mathrm{Zn}$ \\
\hline As & 1 & & & & & & & & & & \\
$\mathrm{Cd}$ & $\mathbf{0 . 9 3 9}$ & 1 & & & & & & & & \\
$\mathrm{Co}$ & $\mathbf{0 . 9 5 6}$ & $\mathbf{0 . 9 9 1}$ & 1 & & & & & & & & \\
$\mathrm{Cr}$ & $\mathbf{0 . 9 8 7}$ & $\mathbf{0 . 9 7 8}$ & $\mathbf{0 . 9 9 0}$ & 1 & & & & & & \\
$\mathrm{Cu}$ & -.790 & -0.945 & -.898 & -.859 & 1 & & & & & & \\
$\mathrm{Fe}$ & $\mathbf{0 . 9 9 6}$ & $\mathbf{0 . 9 3 5}$ & $\mathbf{0 . 9 6 2}$ & $\mathbf{0 . 9 8 8}$ & -0.772 & 1 & & & & & \\
$\mathrm{Hg}$ & $\mathbf{0 . 9 5 1}$ & $\mathbf{0 . 9 9 8}$ & $\mathbf{0 . 9 9 8}$ & $\mathbf{0 . 9 8 7}$ & -0.923 & $\mathbf{0 . 9 5 2}$ & 1 & & & & \\
$\mathrm{Mn}$ & $\mathbf{0 . 9 7 7}$ & $\mathbf{0 . 9 3 8}$ & $\mathbf{0 . 9 7 2}$ & $\mathbf{0 . 9 8 5}$ & -0.773 & $\mathbf{0 . 9 9 2}$ & $\mathbf{0 . 9 5 8}$ & 1 & & & \\
$\mathrm{Ni}$ & $\mathbf{0 . 6 4 6}$ & $\mathbf{0 . 6 1 6}$ & $\mathbf{0 . 7 0 9}$ & $\mathbf{0 . 6 8 3}$ & -0.401 & $\mathbf{0 . 7 1 3}$ & $\mathbf{0 . 6 6 3}$ & $\mathbf{0 . 7 8 8}$ & 1 & & \\
$\mathrm{~Pb}$ & $\mathbf{0 . 6 2 8}$ & $\mathbf{0 . 7 9 0}$ & $\mathbf{0 . 8 1 6}$ & $\mathbf{0 . 7 3 5}$ & -0.754 & $\mathbf{0 . 6 7 3}$ & $\mathbf{0 . 8 0 2}$ & $\mathbf{0 . 7 5 3}$ & 0.817 & 1 & \\
$\mathrm{Zn}$ & -0.916 & -0.751 & -0.762 & -0.844 & 0.577 & -0.890 & -0.761 & -0.827 & -0.396 & -0.265 & 1 \\
\hline
\end{tabular}

Bold values are significant at $p<0.001$

\subsection{Health risk assessment}

US-EPA has introduced health risk (carcinogenic and noncarcinogenic health risk) parameters to determine the health risk due to the exposure of toxic metals when used for a long time [50].

\subsubsection{Estimated daily intake}

EDI refers to the estimated daily intake. The calculation is based on each metal's mean concentration in food and respective consumption of rate and done by Eq. (2), and data are displayed in Table 10. By comparing these values with the reference value, we determined that EDI values for heavy metals $\mathrm{As}, \mathrm{Co}$, and $\mathrm{Hg}$ were high and calculated for both adults and children. The NYSDOH (New York State Department of Health) suggests if $\mathrm{EDI} / D_{\mathrm{f}}$ ratio is $\leq D_{\mathrm{f}}$ it is related to minimum health risk. If it is $1-5$ times higher than $D_{\mathrm{f},}$ it is related to low health risk. If it is $5-10$ times higher than Df, it is related to moderate health risk, and if it is ten times higher than $D_{f}$, it is related to high health risk [50]. From EDI/ $D_{\mathrm{f}}$ ratio, we concluded that the As metal in fruity vegetables is $1-5$ higher than $D_{\mathrm{f}}$, so low health risk for using these vegetables grown in this area while in leafy vegetables, it is 5-10 times high so moderate health risk for using this vegetable.

\subsubsection{Target hazard quotient}

THQ is related to the noncarcinogenic health risk, and its acceptable value is $\leq 1$ [51]. Ambedkar and Maniyan (2011) resolved that if THQ values exceed their limit, it will be associated with health risk. It will be calculated by Eq. (3), and its data are shown in Table 11. In this study, the THQ values for $\mathrm{As}, \mathrm{Co}$, and $\mathrm{Hg}$ are greater than 1 in all vegetables. So, their THQ values could carry the noncarcinogenic risk in this area population. From these values, we observed that the leafy vegetables' $T H Q$ values are higher than the fruity vegetables except $\mathrm{Cu}$ and $\mathrm{Zn}$.

\subsubsection{Hazard index}

$\mathrm{HI}$ represents the cumulative effect of the ingestion of toxic metals from the usage of contaminated vegetables, and data of $\mathrm{HI}$ shown in Table 11 indicate that $\mathrm{HI}$ values are higher than the permissible limit (1) for all vegetables. So, this study area's vegetable intake will be linked with noncarcinogenic health risk [42].

It is an allusion here that this present study assessed the EDI, THQ, and HI values which were based on the estimated daily vegetable consumption, which was about $325 \mathrm{~g}$ per day for both study vegetables. So, it is probable that EDI and THQ values might be overvalued and might impact on $\mathrm{HI}$ values as well. Meanwhile, it should be noted that the present study had only considered cabbage, brinjal, okra, and tomato to estimate possible noncarcinogenic and carcinogenic health risks of the population in Kasur and its surrounding. Hence, this study's result took into account part but not the real threat to the people in the study area. As a result, the local population's potential health risks due to the exposure to heavy metals through the consumption of vegetables might be underestimated. 
Table 8 Total variance explained and component matrices for the heavy metals in vegetables

\begin{tabular}{|c|c|c|c|c|c|c|c|c|c|}
\hline \multirow[t]{2}{*}{ Component } & \multicolumn{3}{|c|}{ Initial eigenvalues } & \multicolumn{3}{|c|}{ Extraction sums of squared loadings } & \multicolumn{3}{|c|}{ Rotation sums of squared loadings } \\
\hline & Total & $\%$ of Variance & Cumulative \% & Total & $\%$ of Variance & Cumulative \% & Total & $\%$ of Variance & Cumulative $\%$ \\
\hline 1 & 9.350 & 84.996 & 84.996 & 9.350 & 84.996 & 84.996 & 6.249 & 56.806 & 56.806 \\
\hline 2 & 1.004 & 9.129 & 94.125 & 1.004 & 9.129 & 94.125 & 4.105 & 37.319 & 94.125 \\
\hline 3 & 0.646 & 5.875 & 95.321 & & & & & & \\
\hline 4 & $1.4 \mathrm{E}-15$ & $1.2 \mathrm{E}-14$ & 97.234 & & & & & & \\
\hline 5 & $3.9 \mathrm{E}-16$ & $3.5 \mathrm{E}-15$ & 100 & & & & & & \\
\hline 6 & $3.1 \mathrm{E}-16$ & $2.8 \mathrm{E}-15$ & 100 & & & & & & \\
\hline 7 & $1.9 \mathrm{E}-16$ & $1.8 \mathrm{E}-15$ & 100 & & & & & & \\
\hline 8 & $1.1 \mathrm{E}-17$ & $1.0 \mathrm{E}-16$ & 100 & & & & & & \\
\hline 9 & $-1.2 \mathrm{E}-16$ & $-1.1 \mathrm{E}-15$ & 100 & & & & & & \\
\hline 10 & $-2.0 \mathrm{E}-16$ & $-1.8 \mathrm{E}-15$ & 100 & & & & & & \\
\hline 11 & $-1.0 \mathrm{E}-15$ & $-9.2 \mathrm{E}-15$ & 100 & & & & & & \\
\hline \multirow[t]{2}{*}{ Elements } & \multicolumn{2}{|c|}{ Component matrix } & \multicolumn{3}{|c|}{ Rotated component matrix } & & & & \\
\hline & PC1 & PC2 & PC1 & PC2 & & & & & \\
\hline Co & 0.997 & & -0.979 & & & & & & \\
\hline $\mathrm{Cr}$ & 0.996 & & 0.901 & 0.424 & & & & & \\
\hline $\mathrm{Hg}$ & 0.992 & & 0.861 & 0.487 & & & & & \\
\hline $\mathrm{Mn}$ & 0.987 & & 0.841 & 0.541 & & & & & \\
\hline $\mathrm{Cd}$ & 0.981 & & 0.790 & 0.592 & & & & & \\
\hline $\mathrm{Fe}$ & 0.980 & & 0.784 & 0.591 & & & & & \\
\hline As & 0.973 & -0.213 & 0.781 & 0.611 & & & & & \\
\hline $\mathrm{Cu}$ & -0.866 & & 0.768 & 0.637 & & & & & \\
\hline $\mathrm{Zn}$ & -0.798 & 0.568 & -0.670 & -0.548 & & & & & \\
\hline $\mathrm{Pb}$ & 0.789 & 0.605 & 0.257 & 0.960 & & & & & \\
\hline $\mathrm{Ni}$ & 0.726 & 0.492 & 0.276 & 0.832 & & & & & \\
\hline
\end{tabular}

Fig. 2 Principal component analysis of a vegetable sample collected from the Kasur region

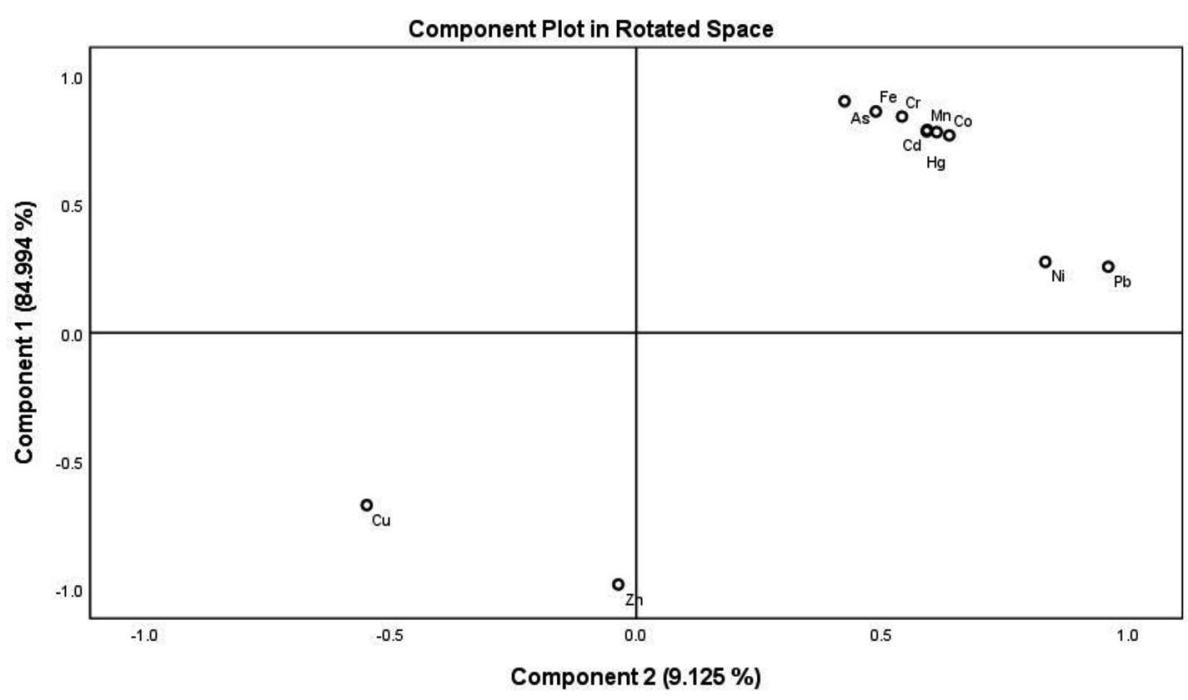


Table 9 BCF of heavy metals calculated for tomato, brinjal, cabbage, and okra

\begin{tabular}{lllll}
\hline Metals & \multicolumn{4}{l}{ Bioconcentration factor (BCF) } \\
\cline { 2 - 5 } & Tomato & Brinjal & Cabbage & Okra \\
\hline $\mathrm{As}$ & 0.08 & 0.12 & 0.20 & 0.10 \\
$\mathrm{Cd}$ & 0.10 & 0.12 & 0.16 & 0.09 \\
$\mathrm{Co}$ & 0.09 & 0.11 & 0.18 & 0.08 \\
$\mathrm{Cr}$ & 0.06 & 0.10 & 0.18 & 0.06 \\
$\mathrm{Cu}$ & 0.53 & 0.48 & 0.38 & 0.61 \\
$\mathrm{Fe}$ & 1.55 & 1.88 & 2.49 & 1.84 \\
$\mathrm{Hg}$ & 9.35 & 11.00 & 9.78 & 8.71 \\
$\mathrm{Mn}$ & 0.03 & 0.03 & 0.10 & 0.03 \\
$\mathrm{Ni}$ & 0.11 & 0.06 & 0.14 & 0.08 \\
$\mathrm{~Pb}$ & 0.08 & 0.08 & 0.10 & 0.06 \\
$\mathrm{Zn}$ & 0.25 & 0.23 & 0.22 & 0.23 \\
\hline
\end{tabular}

\subsubsection{Target cancer risk}

Overall, it is supposed that when people interact with toxic metals, it may produce the bad effect on their health, and prolonged contact with specific carcinogenic metal may lead to cancer, and heal risk increases with time. TCR signifies the approximation of the predictable cancers. Then, it also signifies the opportunity to evolve cancer-causing risks in an individual. TCR is due to the exposure of toxic metals such as $\mathrm{As}, \mathrm{Cd}, \mathrm{Cr}, \mathrm{Ni}$, and $\mathrm{Pb}$ by consuming contaminated vegetables calculated by EDI and CPS, values and obtained result shown in Table 12. NYSDOH stated that If TCR values are $\leq 10^{-6}$, then it relates to low cancercausing risks, if its values lie between $10^{-5}$ and $10^{-4}$, then it relates to moderate cancer-causing risks, and if values lie between $10^{-3}$ and $10^{-1}$, then it relates to high stakes [50].

TCR values for $\mathrm{As}$ and $\mathrm{Ni}$ for all vegetables stay in the $10^{-3}-10^{-1}$, indicating the high carcinogenic risk. While the TCR value of $\mathrm{Cr}$ in cabbage also remains $10^{-3}-10^{-1}$, it also shows the high risk. All other TCR values for all metals are within the $10^{-5}-10^{-4}$ range, so these relate to the moderate cancer risk.

\section{Conclusion}

This study indicated that heavy metal concentration in groundwater is high from FAO's standard range. The mean concentration of $\mathrm{As}, \mathrm{Cd}, \mathrm{Cu}, \mathrm{Pb}$, and $\mathrm{Zn}$ in soil samples is higher than the permissible range. Similarly, heavy metals such as $\mathrm{As}, \mathrm{Cd}, \mathrm{Pb}, \mathrm{Cr}, \mathrm{Fe}, \mathrm{Hg}$, and $\mathrm{Mn}$ values exceeded the recommended values set by $\mathrm{FAO} / \mathrm{WHO}$ in all vegetable samples. From human health point of view, THQ values of As (2.67), Co (1.01), and $\mathrm{Hg}$ (3.30) by consumption of tomato are' 1. Similarly, THQ values of As (4.07), Co (1.29), and $\mathrm{Hg}$ (3.55) by consumption of brinjal are' 1 . The GTHQ

Table 10 EDI of heavy metals for adult and children by consumption of contaminated vegetables

\begin{tabular}{|c|c|c|c|c|c|c|c|c|c|c|}
\hline \multirow[t]{3}{*}{ Heavy metals } & \multicolumn{8}{|c|}{ EDI values (mg/day/kg weight) } & \multirow{3}{*}{$\begin{array}{l}\text { TEDI } \\
\text { adult }\end{array}$} & \multirow{3}{*}{$\begin{array}{l}\text { TEDI } \\
\text { children }\end{array}$} \\
\hline & \multicolumn{4}{|l|}{ Adult } & \multicolumn{4}{|l|}{ Children } & & \\
\hline & Tomato & Brinjal & Cabbage & Okra & Tomato & Brinjal & Cabbage & Okra & & \\
\hline As & 0.0007 & 0.0010 & 0.0018 & 0.0009 & 0.0011 & 0.0017 & 0.0030 & 0.0015 & 0.0044 & 0.0073 \\
\hline $\mathrm{Cd}$ & 0.0002 & 0.0002 & 0.0003 & 0.0002 & 0.0003 & 0.0003 & 0.0004 & 0.0003 & 0.0008 & 0.0013 \\
\hline Co & 0.0011 & 0.0010 & 0.0013 & 0.0008 & 0.0019 & 0.0017 & 0.0021 & 0.0014 & 0.0042 & 0.0070 \\
\hline $\mathrm{Cr}$ & 0.0003 & 0.0003 & 0.0005 & 0.0002 & 0.0004 & 0.0005 & 0.0009 & 0.0004 & 0.0014 & 0.0022 \\
\hline $\mathrm{Cu}$ & 0.0049 & 0.0040 & 0.0036 & 0.0054 & 0.0081 & 0.0067 & 0.0060 & 0.0089 & 0.0180 & 0.0297 \\
\hline $\mathrm{Fe}$ & 0.0006 & 0.0009 & 0.0018 & 0.0006 & 0.0009 & 0.0015 & 0.0030 & 0.0010 & 0.0039 & 0.0065 \\
\hline $\mathrm{Hg}$ & 0.0344 & 0.0388 & 0.0534 & 0.0372 & 0.0568 & 0.0641 & 0.0881 & 0.0615 & 0.1638 & 0.2704 \\
\hline $\mathrm{Mn}$ & 0.0008 & 0.0009 & 0.0010 & 0.0008 & 0.0014 & 0.0015 & 0.0017 & 0.0014 & 0.0036 & 0.0060 \\
\hline $\mathrm{Ni}$ & 0.0132 & 0.0179 & 0.0510 & 0.0143 & 0.0218 & 0.0296 & 0.0843 & 0.0235 & 0.0964 & 0.1591 \\
\hline $\mathrm{Pb}$ & 0.0009 & 0.0005 & 0.0012 & 0.0007 & 0.0015 & 0.0009 & 0.0020 & 0.0011 & 0.0034 & 0.0056 \\
\hline $\mathrm{Zn}$ & 0.0089 & 0.0085 & 0.0080 & 0.0084 & 0.0148 & 0.0140 & 0.0133 & 0.0139 & 0.0339 & 0.0560 \\
\hline
\end{tabular}


Table 11 THQ to toxic metals due to consumption of contaminated vegetables in Kasur region

\begin{tabular}{|c|c|c|c|c|c|c|c|c|c|c|}
\hline \multirow[t]{2}{*}{ Metals } & \multicolumn{4}{|c|}{ THQ adult ${ }^{\mathrm{c}}$} & \multicolumn{4}{|c|}{ THQ children ${ }^{c}$} & \multirow{2}{*}{$\begin{array}{l}\mathrm{GTHQ}^{\mathrm{a}} \\
\text { adult }\end{array}$} & \multirow{2}{*}{$\begin{array}{l}\mathrm{GTHQ}^{\mathrm{a}} \\
\text { children }\end{array}$} \\
\hline & Tomato & Brinjal & Cabbage & Okra & Tomato & Brinjal & Cabbage & Okra & & \\
\hline As & 2.30 & 3.49 & 6.00 & 3.04 & 3.80 & 5.76 & 9.91 & 5.02 & 14.83 & 24.48 \\
\hline $\mathrm{Cd}$ & 0.17 & 0.21 & 0.26 & 0.16 & 0.29 & 0.35 & 0.44 & 0.27 & 0.81 & 1.34 \\
\hline Co & 3.74 & 3.37 & 4.22 & 2.79 & 6.17 & 5.56 & 6.97 & 4.61 & 14.12 & 23.31 \\
\hline $\mathrm{Cr}$ & 0.09 & 0.11 & 0.18 & 0.07 & 0.14 & 0.18 & 0.30 & 0.12 & 0.45 & 0.75 \\
\hline $\mathrm{Cu}$ & 0.12 & 0.10 & 0.09 & 0.13 & 0.20 & 0.17 & 0.15 & 0.22 & 0.45 & 0.74 \\
\hline $\mathrm{Fe}$ & 0.0008 & 0.0013 & 0.0026 & 0.0009 & 0.0013 & 0.0022 & 0.0042 & 0.0015 & 0.01 & 0.01 \\
\hline $\mathrm{Hg}$ & 1.72 & 1.94 & 2.67 & 1.86 & 2.84 & 3.20 & 4.41 & 3.07 & 8.19 & 13.52 \\
\hline $\mathrm{Mn}$ & 0.01 & 0.01 & 0.01 & 0.01 & 0.01 & 0.01 & 0.01 & 0.01 & 0.03 & 0.04 \\
\hline $\mathrm{Ni}$ & 0.66 & 0.90 & 2.55 & 0.71 & 1.09 & 1.48 & 4.21 & 1.18 & 4.82 & 7.96 \\
\hline $\mathrm{Pb}$ & 0.26 & 0.15 & 0.35 & 0.20 & 0.44 & 0.25 & 0.58 & 0.33 & 0.97 & 1.60 \\
\hline $\mathrm{Zn}$ & 0.03 & 0.03 & 0.03 & 0.03 & 0.05 & 0.05 & 0.04 & 0.05 & 0.11 & 0.19 \\
\hline $\mathrm{HI}^{\mathrm{b}}$ & 9.10 & 10.30 & 16.36 & 9.00 & 15.03 & 17.01 & 27.02 & 14.87 & 44.77 & 73.93 \\
\hline
\end{tabular}

${ }^{a}$ GTHQ is the sum of individual metal THQ for each vegetable

${ }^{\mathrm{b}} \mathrm{HI}$ is hazard index

'bold values indicate the values' 1

\begin{tabular}{|c|c|c|c|c|c|c|c|c|}
\hline \multirow[t]{2}{*}{ Metals } & \multicolumn{4}{|l|}{ TCR adult $^{\mathrm{a}}$} & \multicolumn{4}{|c|}{ TCR children ${ }^{a}$} \\
\hline & Tomato & Brinjal & Cabbage & Okra & Tomato & Brinjal & Cabbage & Okra \\
\hline As & 1.05E-03 & $1.50 \mathrm{E}-03$ & 2.70E-03 & 1.35E-03 & 1.65E-03 & 2.55E-03 & 4.50E-03 & 2.25E-03 \\
\hline $\mathrm{Cd}$ & $7.60 \mathrm{E}-05$ & $7.60 \mathrm{E}-05$ & $1.14 \mathrm{E}-04$ & 7.60E-05 & $1.14 \mathrm{E}-04$ & $1.14 \mathrm{E}-04$ & $1.52 \mathrm{E}-04$ & $1.14 \mathrm{E}-04$ \\
\hline $\mathrm{Cr}$ & $1.50 \mathrm{E}-04$ & $1.50 \mathrm{E}-04$ & $2.50 \mathrm{E}-04$ & $1.00 \mathrm{E}-04$ & $2.00 \mathrm{E}-04$ & $2.50 \mathrm{E}-04$ & $4.50 \mathrm{E}-04$ & $2.00 \mathrm{E}-04$ \\
\hline $\mathrm{Ni}$ & 2.24E-02 & 3.04E-02 & 8.67E-02 & 2.43E-02 & 3.71E-02 & 5.03E-02 & 1.43E-01 & 4.00E-02 \\
\hline $\mathrm{Pb}$ & $7.65 \mathrm{E}-06$ & $4.25 \mathrm{E}-06$ & $1.02 \mathrm{E}-05$ & 5.95E-06 & $1.28 \mathrm{E}-05$ & $7.65 \mathrm{E}-06$ & $1.70 \mathrm{E}-05$ & $9.35 \mathrm{E}-06$ \\
\hline
\end{tabular}

Bold values indicates the cancer risk

${ }^{\mathrm{a}}$ indicates the values higher than the US-EPA limits
Table 12 TCR of heavy metals by consumption of contaminated vegetables
Authors' contributions IA and FA conceived the concept. IA and AS designed the experimental work. IA, FA, AS, ARA, and TP collected and analyzed the data. IA prepared the manuscript. ARA and TP proofread the document and correction. All authors approved the final version of the manuscript.

Funding The authors declare that the study was conducted in the absence of any commercial or financial relationships.

\section{Declarations}

Conflicts of interest There are no conflicts of interest.

Availability of data and material All data generated or analyzed during this study are included in this published article [and its supplementary information files]. Further, the datasets used and/or analyzed during the current study are available from the corresponding author on reasonable request. 
Open Access This article is licensed under a Creative Commons Attribution 4.0 International License, which permits use, sharing, adaptation, distribution and reproduction in any medium or format, as long as you give appropriate credit to the original author(s) and the source, provide a link to the Creative Commons licence, and indicate if changes were made. The images or other third party material in this article are included in the article's Creative Commons licence, unless indicated otherwise in a credit line to the material. If material is not included in the article's Creative Commons licence and your intended use is not permitted by statutory regulation or exceeds the permitted use, you will need to obtain permission directly from the copyright holder. To view a copy of this licence, visit http://creativecommons. org/licenses/by/4.0/.

\section{References}

1. Chauhan G, Chauhan UK (2014) Human health risk assessment of heavy metals via dietary intake of vegetables grown in wastewater irrigated area of Rewa, India. Int J Sci Res Pub 4:1-9

2. Butt MS, Sharif K, Bajwa BE, Aziz A (2005) Hazardous effects of sewage water on the environment focus on heavy metals and chemical composition of soil and vegetables. Manag Environ Qual 16:338-346. https://doi.org/10.1108/14777830510601217

3. Jansen E, Michels M, Van TM, Doelman P (1994) Effects of heavy metals in soil on microbial diversity and activity as shown by the sensitivity-resistance index, an ecologically relevant parameters. Biol Fertil Soils 17:177-184. https://doi.org/10.1007/BF003 36319

4. Fergusson JE, Kim ND (1991) Trace elements in street and house dust: sources and speciation. Sci Total Environ 100:125-150. https://doi.org/10.1016/0048-9697(91)90376-P

5. Goyer RA (1997) Toxic and essential metal interactions. Annu Rev Nutr 17:37-50. https://doi.org/10.1146/annurev.nutr.17.1. 37

6. Ma QY, Traina SJ, Logan TJ, Ryan JA (1994) Effects of aqueous Al, $\mathrm{Cd}, \mathrm{Cu}, \mathrm{Fe}$ (II), Ni, and $\mathrm{Zn}$ on Pb immobilization by hydroxyapatite. Environ Sci Technol 28:1219-1228. https://doi.org/10.1021/ es00056a007

7. Msaky JJ, Calvet R (1990) Adsorption behavior of copper and zinc in soils: Influence of $\mathrm{pH}$ on adsorption characteristics. Soil Sci 150:513-522

8. Khan A, Javid S, Muhmood A, Mjeed T, Niaz A, Majeed A (2013) Heavy metal status of soil and vegetables grown on peri-urban area of Lahore district. Soil Environ 32:49-54

9. Hayat S, Ahmad I, Azam ZM, Ahmad A, Inam A, Samiullah, (2002) Effect of long-term application of oil refinery wastewater on soil health with special reference to microbiological characteristics. Bioresour Technol 84:159-163. https://doi.org/10.1016/s09608524(02)00027-5

10. Dehlin S, Witter E, Martensson AM, Turner A, Bååth E (1997) Where is the limit? changes in the microbiological properties of agricultural soils at low levels of metal contamination. Soil Bio Biochem 29:1405-1415. https://doi.org/10.1016/S00380717(97)00048-5

11. Daniels MJ, Turner-Carvet JS, Selkirk R, Sun HZ, Parkison JA, Sadler PJ, Robison NJ (1998) Coordination of $\mathrm{Zn}^{2+}\left(\right.$ and $\mathrm{Cd}^{2+}$ ) by prokaryotic metallothionein: involvement of His-imidazole. J Bio Chem 273:22957-22961. https://doi.org/10.1074/jbc.273. 36.22957

12. $\mathrm{Xu} \mathrm{YB}, \mathrm{Xiao} H \mathrm{HH}$, Sun SY (2005) Study on anaerobic treatment of wastewater containing $\mathrm{Cr}^{6+}$. J Zhejiang Univ Sci B 6:574-579

13. Vatanpour N, Feizy J, Hedayati Talouki H, Es'haghi Z, Scesi L, Malvandi AM (2020) The high levels of heavy metal accumulation in cultivated rice from the Tajan river basin: health and ecological risk assessment. Chemosphere 245:125639. https://doi.org/10. 1016/j.chemosphere.2019.125639

14. Al-Dhabi NA, Esmail GA, Ghilan AKM, Arasu MV (2019) Composting of vegetable waste using microbial consortium and biocontrol efficacy of Streptomyces Sp. Al-Dhabi 30 isolated from the Saudi Arabian environment for sustainable agriculture. Sustainability. https://doi.org/10.3390/su11236845

15. Al-Dhabi NA, Esmail GA, Ghilan AKM, Arasu MV (2019) Optimizing the management of cadmium bioremediation capacity of metal-resistant Pseudomonas sp. strain Al-Dhabi-126 isolated from the industrial city of Saudi Arabian environment. Int J Environ Res Public Health. https://doi.org/10.3390/ijerph16234788

16. Alghobar MA, Suresha S (2017) Evaluation of metal accumulation in soil and tomatoes irrigated with sewage water from Mysore city, Karnataka, India. J Saudi Soc Agric Sci 16:49-59. https://doi.org/10.1016/j.jssas.2015.02.002

17. Ara MH, Khan AR, Uddin N, Dhar PK (2018) Health risk assessment of heavy metals in the leafy, fruit, and root vegetables cultivated near Mongla industrial area, Bangladesh. J Hum Environ Heal Prom 4:144-152. https://doi.org/10.29252/jhehp.4.4.1

18. Kormoker T, Proshad R, Islam MS, Shamsuzzoha M, Akter A, Tusher TR (2020) Concentrations, source apportionment and potential health risk of toxic metals in foodstuffs of Bangladesh. Toxin Rev 40:1-16. https://doi.org/10.1080/15569543.2020. 1731551

19. Proshad R, Kormoker T, Islam MS, Chandra K (2019) Potential health risk of heavy metals via consumption of rice and vegetables grown in the industrial areas of Bangladesh. Hum Ecol Risk Assess Int J 26:921-943. https://doi.org/10.1080/10807039. 2018.1546114

20. Islam MS, Ahmed MK, Proshad R, Ahmed S (2017) Assessment of toxic metals in vegetables with the health implications in Bangladesh. Adv Environ Res 6:241-254. https://doi.org/10.12989/ aer.2017.6.4.241

21. Randhawa MA, Ahmad G, Anjum FM, Asghar A, Sajid MW (2014) Heavy metal contents and their daily intake in vegetables under peri-urban farming system of Multan, Pakistan. Pak J Agric Sci 51:1025-1031

22. Jamali MK, Kazi TG, Arain MB, Afridi HI, Jalbani N, Kandhro GA, Shah AQ, Baig JA (2009) Heavy metal accumulation in different varieties of wheat (Triticum aestivum L.) grown in soil amended with domestic sewage sludge. J Hazard Mater 164:1386-1391. https://doi.org/10.1016/j.jhazmat.2008.09.056

23. Jan FA, Ishaq M, Ihsanullah I, Asim SM (2009) Multivariate statistical analysis of heavy metals pollution in industrial area and its comparison with relatively less polluted area: a case study from the city of Peshawar and District Dir Lower. J Hazard Mater 176:609-616. https://doi.org/10.1016/j.jhazmat.2009.11.073

24. Jan FA, Ishaq $M$, Khan S, Ihsanullah I, Ahmad I, Shakirullah $M$ (2010) A comparative study of human health risks via consumption of food crops grown on wastewater irrigated soil (Peshawar) and relatively clean water irrigated soil (lower Dir). J Hazard Mater 179:612-621. https://doi.org/10.1016/j.jhazmat.2010.03. 047

25. Khan S, Rehman S, Khan AZ, Khan MA, Shah T (2010) Soil and vegetables enrichment with heavy metals from geological sources in Gilgit, northern Pakistan. Ecotoxicol Environ Saf 73:1820-1827. https://doi.org/10.1016/j.ecoenv.2010.08.016

26. Aiman U, Mahmood A, Waheed S, Malik RN (2016) Enrichment, geo-accumulation and risk surveillance of toxic metals for different environmental compartments from Mehmood Booti dumping site, Lahore city, Pakistan. Chemosphere 144:2229-2237. https://doi.org/10.1016/j.chemosphere.2015.10.077

27. Mahmood A, Malik RN (2014) Human health risk assessment of heavy metals via consumption of contaminated vegetables collected from different irrigation sources in Lahore, Pakistan. 
Arab J Chem 7:91-99. https://doi.org/10.1016/j.arabjc.2013.07. 002

28. Tariq SR, Shah MH, Shaheen N (2008) Statistical source identification of metal sin groundwater exposed to industrial contamination. Environ Monit Assess 138:159-165. https://doi.org/10. 1007/s10661-007-9753-8

29. Tariq SR, Shah MH, Shaheen N, Khalique A, Manzoor S, Jaffar M (2005) Multivariate analysis of selected metals in tannery effluents and related soil. J Hazard Mater 122:17-22. https://doi.org/ 10.1016/j.jhazmat.2005.03.017

30. Afzal M, Shabir G, lqbal S, Mustafa T, Khan QM, Khalid ZM (2013) Assessment of heavy metal contamination in soil and groundwater at leather industrial area of Kasur, Pakistan. Clean: Soil, Air, Water 41:1-7. https://doi.org/10.1002/clen.201100715

31. Allen SE, Grimshaw HM, Rowland AP (1986) Chemical Analysis. In: Chapman SB, Moore PD (eds) Methods in plant ecology, London,pp 285-344

32. McLean EO (1982) Soil pH and lime requirement.In: Page AL (ed) Methods of soil analysis, Part 2: chemical and microbiological properties. Am Soc Agron, Madison, WI, USA, pp 199-224

33. Bremner IM, Mulvaney CS (1982) Nitrogen total. In: Page AL (ed) Methods of soil analysis. Agron. No.9, Part 2: chemical and microbiological properties, 2nd edn. Am Soc Agron, Madison, WI, USA, pp 595-624

34. Welz B, Sperling M (1999) Atomic absorption spectrometry, 3rd edn. Wiley-VCH, Verlag GmbH, Weinheim, Germany

35. Ara MH, Mondal UK, Dhar PK, Uddin MN (2018) Presence of heavy metals in vegetables collected from Jashore, Bangladesh: human health risk assessment. J Chem Health Risks 8:277-287. https://doi.org/10.22034/JCHR.2018.544710

36. Olsen SR, Cole CV, Watanabe FS, Dean LA (1954) Estimation of available phosphorus in soils by extraction with sodium bicarbonate. US Department of Agriculture, USA, p 939

37. Tech Rep (1989) Evaluation of certain food additives and contaminants. Technical report series Geneva, 33rd Report of the joint FAO/WHO expert committee on food additives. World Health organization (WHO), Geneva, Switzerland

38. Arora M, Kiran B, Rani S, Rani A, Kaur B, Mittal N (2008) Heavy metal accumulation in vegetables irrigated with water from different sources. Food Chem 111:811-815. https://doi.org/10. 1016/j.foodchem.2008.04.049

39. Tech Rep (1993) Evaluation of certain food additives and contaminants. Technical report series Geneva, 41st Report of the joint FAO/WHO expert committee on food additives. World Health organization (WHO), Geneva, Switzerland

40. Antoine JMR, Fung LAH, Grant CN (2017) Assessment of the potential health risks associated with the aluminum, arsenic, cadmium and lead content in selected fruits and vegetables grown in Jamaica. Toxicol Rep 4:181-187. https://doi.org/10. 1016/j.toxrep.2017.03.006

41. Li X, Li Z, Lin CJ, Bi X, Liu J, Feng X (2018) Health risks of heavy metal exposure through vegetable consumption near a largescale $\mathrm{Pb} / \mathrm{Zn}$ smelter in central China. Ecotoxicol Environ Saf 161:99-110. https://doi.org/10.1016/j.ecoenv.2018.05.080

42. Yang J, Ma S, Zhou J, Song Y, Li F (2018) Heavy metal contamination in soils and vegetables and health risk assessment of inhabitants in Daye, China. J Int Med Res 46:3374-3387. https://doi. org/10.1177/0300060518758585

43. Proshad R, Islam MS, Tusher TR, Zhang D, Khadka S, Gao J, Kundu S (2020) Appraisal of heavy metal toxicity in surface water with human health risk by a novel approach: a study on an urban river in vicinity to industrial areas of Bangladesh. Toxin Rev 40:1-17. https://doi.org/10.1080/15569543.2020.1780615
44. Grag RK, Rao RJ, Uchchariya D, Shukla G, Saksena DN (2010) Seasonal variations in water quality and major threats to Ramsagar reservoir, India. Afr J Environ Sci Technol 4:061-076

45. Ullah R, Malik RN, Qadir A (2009) Assessment of groundwater contamination in an industrial city, Sialkot, Pakistan. Afr J Environ Sci Technol 3:429-446

46. Ul-Haq N, Arain MA, Badar N, Rasheed M, Haque Z (2011) Drinking water: a major source of lead exposure in Karachi, Pakistan. East Mediterr Health J 17:882-886. https://doi.org/10.26719/ 2011.17.11.882

47. Gebeyehu HR, Bayissa LD (2020) Levels of heavy metals in soil and vegetables and associated health risks in mojo area, Ethiopia. PLOS ONE 15:1-22. https://doi.org/10.1371/journal.pone. 0227883

48. Brown JR (1987) Soil testing: sampling, correlation, calibration, and interpretation: proceedings of a symposium. Soil Science Society of America

49. Zafar S, Khan MR (2014) Analysis of Kasur reclaimed soil for the toxicity of heavy metals. J Appl Chem 3:2435-2440

50. McGrath SP, Zhao FJ, Lombi E (2001) Plant and rhizosphere processes involved in phytoremediation of metal-contaminated soils. Plant Soil 232:207-214. https://doi.org/10.1023/A:10103 58708525

51. Rattan RK, Datta SP, Chhonkar PK, Suribabu K, Singh AK (2005) Long-term impact of irrigation with sewage effluents on heavy metal content in soils, crops and groundwater-a case study. Agric Ecosyst Environ 109:310-322. https://doi.org/10.1016/j. agee.2005.02.025

52. Islam MS, Ahmed MK, Al-Mamun MH (2014) Determination of heavy metals in fish and vegetables in Bangladesh and health implications. Hum Ecol Risk Assess Int J 21:986-1006. https:// doi.org/10.1080/10807039.2014.950172

53. Islam MS, Ahmed MK, Al-Mamun MH (2015) Apportionment of heavy metals in soil and vegetables and associated health risks assessment. Stoch Environ Res Risk Assess 30:365-377. https:// doi.org/10.1007/s00477-015-1126-1

54. Bai J, Huang L, Yan D, Wang Q et al (2011) Contamination characteristics of heavy metals in wetland soils along a tidal ditch of the Yellow River Estuary, China. Stoch Environ Res Risk Assess 25:671-676. https://doi.org/10.1007/s00477-011-0475-7

55. Iqbal HH, Taseer R, Anwar S, Qadir A, Shahid N (2016) Human health risk assessment: heavy metal contamination of vegetables in Bahawalpur, Pakistan. Environ Sci 1:10-17

56. Khan K, Lu Y, Khan H, Ishtiaq M, Khan S, Waqas M, Wei L, Wang $T$ (2013) Heavy metals in agricultural soils and crops and their health risks in Swat District, northern Pakistan. Food Chem Toxicol 58:449-458. https://doi.org/10.1016/j.fct.2013.05.014

57. Shaheen N, Irfan NM, Khan IN, Islam S, Islam MS, Ahmed MK (2016) Presence of heavy metals in fruits and vegetables: health risk implications in Bangladesh. Chemosphere 152:431-438. https://doi.org/10.1016/j.chemosphere.2016.02.060

58. Sharma S, Nagpal AK, Kaur I (2018) Heavy metal contamination in soil, food crops and associated health risks for residents of Ropar wetland, Punjab, India and its environs. Food Chem 255:15-22. https://doi.org/10.1016/j.foodchem.2018.02.037

59. Rehman K, Bukhari SM, Andleeb S, Mahmood A, Erinlec KO, Naeem MM, Imran Q (2019) Ecological risk assessment of heavy metals in vegetables irrigated with groundwater and wastewater: the particular case of Sahiwal district in Pakistan. Agric Water Manag 226:105816. https://doi.org/10.1016/j.agwat.2019. 105816

60. Franco-Uria A, Lopez-Mateo C, Roca E (2009) Source identification of heavy metals in pasture land by multivariate analysis in 
NW Spain. J Hazard Mater 1651:8-15. https://doi.org/10.1016/j. jhazmat.2008.10.118

61. Kikuchi T, Furuichi T, Hai HT (2009) Assessment of heavy metal pollution in river water of Hanoi, Vietnam using multivariate analyses. Bull Environ Contam Toxicol 83:575-582. https://doi. org/10.1007/s00128-009-9815-4

62. USEPA (2010) Risk based concentration table. http://www.epa. gov/reg3hwmd/risk/human/index.htm.
63. USEPA (2006) USEPA Region III risk-based concentration table: technical back-ground information. Unites States Environmental Protection Agency, Washington

Publisher's Note Springer Nature remains neutral with regard to jurisdictional claims in published maps and institutional affiliations. 